\title{
PRECONDITIONS OF CRIMINAL LAW PROTECTION OF THE INTERNATIONAL CIRCULATION OF ENDANGERED SPICEMEN OF SPECIES OF WILD FAUNA AND FLORA UNDER CRIMINAL LAW OF LATVIA
}

In the paper, the necessity of protection of legally correct international circulation of endangered species of wild fauna and flora is founded and the customs role in ensuring legally correct international circulation of them is clarified. Analysing international, regional (European Union) and local (the Criminal Law and the Administrative Violations Code of Latvia) legislation the preconditions of criminal liability of violations of the trading provisions of endangered species of wild fauna and flora are determined: (1) object of the criminal offence is specified, (2) term ,trading provisions" is definated, (3) substantial harm as negative consequences caused by the criminal offence is characterised. It is concluded that section 115.1 ,, Violation of the Trading Provisions of Specimens of Endangered Wild Animal and Plant Species" of the Criminal Law needs doctrinal explanation to increase the effectiveness of this rule of law. The constituent elements of the criminal offence described in the section 115.1 of the Criminal Law is analysed to promote its application in accordance with its sense and purpose taking into account international obligations to raise the protection level of the endangered species of fauna and flora involved in the international trade. In order to fulfil the demand of the international public for the effective fight against the environmental crime, it is necessary to not only strengthen the understanding of the preconditions to protection of the endangered species under criminal law, but also the states must follow a more unified approach in establishment of the preconditions of criminal liability.

Key words: endangered species of fauna and flora, the Convention on International Trade in Endangered Species of Wild Fauna and Flora (CITES), criminal liability, customs, illicit trade, international circulation of goods, international trade.

JEL Classification: K14.

Toms ČEVERS,

University of Latvia, Riga, Latvia

toms.cevers@gmail.com

\section{Topicality of Protection of Endangered Species of Wild} Fauna and Flora under Criminal Law

Extracurricular attention to necessity, provision and effectivity of protection of endangered species of wild fauna and flora is urged by passing the $45^{\text {th }}$ anniversary of concluding one of the most important multilateral environmental agreementsat this very moment putting aside disputes about its successfulness ${ }^{1}-$ "The Convention on International Trade in Endangered Species of Wild Fauna and Flora" or CITES.

\footnotetext{
${ }^{1}$ Wijnstekers W. The Evolution of CITES - 9th Edition. International Council for Game and Wildlife Conservation, 2011, page 25. Accesible: https:// cites.org/sites/default/files/common/resources/Evolution of CITES 9.pdf (03.11.2018.); Daan P. van Uhm. The Illegal Wildlife Trade: Inside theWorld of Poachers, Smugglers and Traders. Springer International Publishing Switzwerland, 2016, p. 36, 41

${ }^{2}$ Par starptautisko tirdzniecību ar apdraudētajām savvaḷas dzīvnieku un augu sugām: 1973.gada 3.marta starptautisks līgums. Latvijas Vēstnesis, 1997. 7.janvāris, Nr. 3/4
} 
Despite the fact that the international community has been taking care of protection of wildlife for five decades, the environment is still under an intensive threat - it is estimated that today the fourth largest crime in the world has become a sector of environmental crime. ${ }^{3}$ First, illegal harvesting, processing and trade in protected nature are an important source of income for organized crime. Secondly, the sustained economic growth has boosted people's disposable income and hence their ability to purchase luxury and desirable wildlife products, without taking into account the consequences of their choices. ${ }^{4}$

The value of goods is significantly affected by their accessibility. Taking into account that constant obtaining and trade of natural resources depletes nature, then value of wildlife only increases, which yet again promotes its illegal circulation and thus creates a hardly severable vicious circle. $^{5}$

In light of the above, protection of the environment is on the agenda of transnational organizations. Looking through the annual illicit trade reports of the World Customs Organization, it can be concluded that merely their structure signals tendency towards unlawful circulation of goods. ${ }^{6}$ It is defined that from 2013 to 2015 environment issues are viewed right after evaluation of the work performance of the customs offices in the field of combating the drug trafficking, which demonstrates paying strengthened attention to natural hazard. Though it must be noted that the report of 2016 is introduced with care towards protection of cultural heritage, in this way immediately corresponding with harmful activity of terrorist organizations in the invaluable regions of heritage of the Middle East.

As the European Union (EU), as the focal point ${ }^{7}$ for trafficking in endangered species of wild fauna and flora, has developed an EU Action Plan ${ }^{8}$ to address this phenomenon in the EU and to strengthen the role of the EU in combating it throughout the world. One of the priorities identified for the planned activities is to increase the effectiveness of the implementation of existing rules and the fight against organized crime.

Although the importance of environmental protection is obvious, it is worth reminding the preamble to CITES that wildlife and flora in their many diverse and beautiful forms are no irreplaceable part of the natural system of the Earth that must be protected for this and future generations, through the growth of the value of wildlife and flora from aesthetic, cultural, scientific, economic and recreational points of view. It must be recognized that climate change, wildlife

\footnotetext{
${ }^{3}$ World Customs organization. Illicit Trade Report 2016, page 106. Accesible: http://www.wcoomd.org/-/media/ $\mathrm{wco} / \mathrm{public} / \mathrm{global} / \mathrm{pdf} /$ topics/enforcement-and-compliance/activities-and-programmes/illicit-trade-report/itr2016-en.pdf?db=web (03.11.2018.)

${ }^{4}$ Commission Staff Working Document on the EU Action Plan against Wildlife Trafficking. European Commision. Brussels, SWD/2016/038 final, page 7, 8, 10. Accesible: https://eur-lex.europa.eu/legal-content/EN/ TXT/?uri=SWD:2016:38:FIN (03.11.2018.)

${ }^{5}$ Ignats M., Gulbis A. 1973. gada Vašingtonas konvencijas par starptautisko tirdzniecību ar apdraudētajām dzīvnieku un augu sugām (CITES) noteikumi un to piemērošana. Rīga: RTU Muitas konsultatīvais centrs, 2003, 3.lpp.

${ }^{6}$ Accesible: http://www.wcoomd.org/en/topics/enforcement-and-compliance/resources/publications.aspx(03.11.2018.)

7 The EU is not only one of the transit regions of endangered species of wild fauna and flora, but also the biggest destination of the illegal import. (Commission Staff Working Document on the EU Action Plan against Wildlife Trafficking. European Commision. Brussels, SWD/2016/038 final, page 4, 15, 16. Accesible: https://eur-lex. europa.eu/legal-content/EN/TXT/?uri=SWD:2016:38:FIN (03.11.2018.)

${ }^{8}$ Action Plan against Wildlife Trafficking, European Commision. Brussels, COM/2016/087 final. Accesible: https:// eur-lex.europa.eu/legal-content/EN/TXT/PDF/?uri=CELEX:52016DC0087\&from=EN (03.11.2018.)); Action Plan is demonstratively explained in the publication: European Union. EU Action Plan against Wildlife Trafficking, European Commision (COM (2016) 87 final). Luxembourg: Publications Office of the European Union, 2016. doi:10.2779/016138. Accesible: http://ec.europa.eu/environment/cites/pdf/WAP_EN_WEB.PDF (03.11.2018.)
} 
trade, habitat loss, and the spread of invasive species are one of the most serious threats to biodiversity around the world. Together with direct consequences, the loss of wildlife and flora is associated with wildlife trade, which can change the structure of entire ecosystems and thus affect their balance, undermining their functions and services they provide. ${ }^{9}$

By providing criminal liability for illegal movement of the endangered fauna and flora, the influence and authority of CITES is strengthened, since including of species in the appendixes of CITES alone, does not secure achieving the purposes of CITES. To promote comprehension of the endangerment of the respective species, to reduce demand, supply and to provide sustainability of environment, it is crucial to meet the requirements of CITES in practice.${ }^{10} \mathrm{Consequently}$ provision of criminal liability is a measure for protection of environment as a whole, specifically the procedures for the trade in endangered species of wild fauna and flora together with the specimens of species of endangered fauna and flora themselves.

\section{Customs office's role in the environmental protection}

Effective operational activity of the customs office is a guarantee of operational efficiency of CITES and a prerequisite for applying criminal liability for violations of international trade in endangered species of wild fauna and flora, because, when illegal movement cases are identified on the state border, the mover of goods is established along with conditions of the movement, which provides broader possibilities to detect other levels of illegal trade.

The customs office ensures the established order for the trade in endangered species in accordance with laws and regulations of the State. The purpose of this order is to control the goods imported and exported from the state in order to further the achieving of the set objectives of strategical progress along with protecting values that are significant to the state. By controlling the flow of goods over the national border and by precluding free movement of conventionally prohibited or limited availability goods, the customs office indirectly safeguards nature protection. Therefore this service directly works to prevent threats to public accessibility and preservability of the nature and implements the goal of customs activities which is directed to securing the function ${ }^{11}$ of protection of environment. Relevantly Latvian legislator has taken into account the specific character of illegal movement of the endangered specimens of wild fauna and flora by providing criminal liability in the Chapter 11 of the Criminal Law "Criminal Offences against the Environment" along with a more severe sanction than for smuggling (Section 190) or for movement of goods and unlawful actions with goods subject to customs control (Section 191).

\footnotetext{
${ }^{9}$ Commission Staff Working Document on the EU Action Plan against Wildlife Trafficking. European Commision. Brussels, SWD/2016/038 final, page 27. Accesible: https://eur-lex.europa.eu/legal-content/EN/TXT/?uri=SWD:2016:38:FIN (03.11.2018.); Emphasizing directly the loss of habitats as the main reason for extinction of the endangered species, critical remarks regarding significance of CITES in preserving the biological diversity have been made (A du Plessis Morne. CITES and the Causes of Extinction. Book: Endangered Species, Threatened Convention: The Past, Present and Future of CITES. Edited by Jon Hutton and Barnabus Dickson. London: Earthscan Publications Ltd, 2000, p. 22-23)

${ }^{10}$ Martin R.B. When CITES Works and when it Does Not. Book: Endangered Species, Threatened Convention: The Past, Present and Future of CITES. Edited by Jon Hutton and Barnabus Dickson. London: Earthscan Publications Ltd, 2000, p. 32

${ }^{11}$ Gulbis A., Čevers A. Muitas darbības pamati. Papildināts un pārstrādāts izdevums. Rīga: RTU Izdevniecība, 2010, 27., 28.lpp.
} 
Being aware that there is a comparatively small amount of such endangered species of wild fauna and flora situated in the geographical area of Latvia ${ }^{12}$, by controlling the flow of goods and by implementing criminal liability, the customs offices of Latvia maintain protection of interests of the whole international community, which not only confirms intellectual maturity of the modern society, but also enforces the principle that international problems require international solutions, which is again one of the keynotes of CITES. ${ }^{13}$ Besides being a country of the EU, which establishes its external border and thus serves as the first obstacle for access to the single market, Latvia has increased responsibility in fulfilment of formalities of the customs, because further in the territory of the EU the internal customs borders are abolished and detection of illegal movement can be only occasional.

\section{Procedures for the circulation of the specimens of endangered species of wild fauna} and flora

Circulation of the specimens of endangered species of wild fauna and flora is regulated on three levels. Firstly, international circulation procedures are established in the CITES which is legally binding for Latvia since 3 January 1997, with its purpose to prevent the extinction of the already endangered speciesand to prevent also the risk of extinction occurring directly due to the international trade. Secondly, the procedures for circulation of endangered specimens of species regionally, on the EU level are established in the so called European Union Wildlife Trade Regulations, which include several regulations including Council Regulation (EC) No 338/97 of 9 December 1996 on the protection of species of wild fauna and flora by regulating trade therein ${ }^{14}$ (hereafter - Basic Regulation) and Commission Regulation (EC) No 865/2006 of 4 May 2006 about the establishment of detailed rules for implementation of Council Regulation (EC) No 338/97 on the protection of species of wild fauna and flora by regulating trade therein ${ }^{15}$ (hereafter - Implementation Regulation). Thirdly, on a native level circulation of endangered species of wild flora and fauna is regulated in the national legislation - in Latvia, for example, activities with animals and plants of the specially protected species are regulated in Sections 11 and 12 of the Law On the Conservation of Species and Biotopes ${ }^{16}$.

Taking into account the nonexistence of systematic border control on the internal borders of member states of the EU due to the single market and confirming its engagement in protection of the environment, the EU has in its regulations, which are directly applicable normative acts, not only fully covered the regulation of CITES, but also made the internationally established

\footnotetext{
${ }^{12}$ Specimens of endangered species in Latvia are affected the least by international trade, because conservation of species is mainly affected by the decrease of quality and space of the habitats (1973.gada Vašingtonas konvencijas par tirdzniecību ar apdraudētajām savvaḷas dzīvnieku un augu sugām (CITES) ieviešana Eiropas Savienībā un Latvijā. Autoru kolektīvs. [B.v.]: Dabas aizsardzības pārvalde, [b.g.], 50.lpp. Accesible: https:// www.daba.gov.lv/upload/File/Publikacijas/ROKASGR_CITES_2008.pdf (03.11.2018.))

${ }^{13}$ European Union. Wildlife Trade Regulations in the European Union. Luxembourg: Publications Office of the European Union, 2010, doi:10.2779/21758, page 8. Accesible: http://ec.europa.eu/environment/cites/pdf/ trade regulations/short ref guide.pdf (03.11.2018.); Wijnstekers W. The Evolution of CITES - 9th Edition. International Council for Game and Wildlife Conservation, 2011, page 32. Accesible: https://cites.org/sites/ default/files/common/resources/Evolution_of_CITES_9.pdf (03.11.2018.)

${ }^{14}$ Padomes Regula (EK) Nr. 338/97 (1996. gada 9. decembris) par savval̦as dzīvnieku un augu sugu aizsardzību, reglamentējot to tirdzniecību. Eiropas Savienības Oficiālais Vēstnesis, L' 61, 3.3.1997., 1.-69.lpp.

${ }^{15}$ Komisijas Regula (EK) Nr. 865/2006 (2006. gada 4. maijs), ar ko paredz sīki izstrādātus noteikumus attiecībā uz Padomes Regulas Nr. 338/97 par savval̦as dzīvnieku un augu sugu aizsardzību, reglamentējot to tirdzniecību, ieviešanu. Eiropas Savienības Oficiālais V̉ēstnesis, L 166, 19.6.2006., 1.-69.1pp.

${ }^{16}$ Sugu un biotopu aizsardzības likums: Latvijas Republikas 2000. gada 16. marta likums. Latvijas Vēstnesis, 2000. 5. aprīlis, Nr. 121/122
} 
obligations significantly stronger. In this way within the EU, by observing the established procedures of circulation of the endangered specimens, the demands of CITES are fully met and violations of the international trade are judged in context of the EU law.Trade in specimens of endangered species of wild fauna and flora is permitted, however not preferable, why it is possible by solely complying with the requirements of the EU and thus also of the CITES, which, when implemented, inevitably delays international circulation of goods.

The acts of legislation of the EU based on the CITES regulations provide a scrupulously developed and depending on the specifics of the movable specimen, at times even a casuistic trade procedure ${ }^{17}$, however at the same time principles of trade included in the CITES are preserved. Firstly, the more endangered the species, the bigger the obstacles are established, to permit their trade. Moreover, commercialtrade of the most protected specimens (Article 1 Paragraph 1 of the Basic Regulation) is prohibited. Secondly, permitted trade is based on a permits and certificates system, meaning, in accordance with the chosen activity with the movable specimen (import, export, re-export or introduction from the sea) and the classification of this specimen under the annexes of the Basic Regulation, a permit or certificate shall be issued pursuant to established criteria (Article 4 Paragraph 1-4, Article 5 Paragraph 2-4 of the Basic regulation).Furthermore, each instance of movement requires a separate permit or certificate and the documents necessary must be submitted to the customs offices prior to crossing the border (Article 13 Paragraph 2 of the Implementation Regulation).

Although, considering the existentially fundamental free trade principle of the EU, no obstacles for movement of goods should exist within the EU, still, taking into account the vulnerability of the specimens of endangered wild flora and fauna, as well as to provide protection of the them in accordance with the purpose of international regulations, there are certain procedures for their movement between Member States of the EU. Although movement permits are not required, in case of movement of live specimens listed in Annex A of the Basic Regulation, for example, a prior authorization (a granted certificate) of the governing body of the Member State in which the sample is located (Article 9 of the Basic Regulation). In light of the aforementioned it can be concluded that instances of unlawful movement can be detected not only in trade relations with the third countries, but also within the EU.

\section{Liability for trade in endangered wild animals and plant species}

In Latvia liability is prescribed for violations of the regulatory enactments regarding the international trade since 17 July 2003, in Section 79 of the Latvian Administrative Violations Code, where the constituent elements of the administrative offense are defined: "Violation of the Regulatory Enactments regarding the International Trade of Rare or Endangered Animals and Specimens of Threatened Plant Species and Their Parts".

Considering that the Criminal Law came into force on 1 April 1999, but a relevant crime, precisely, Section 115." "Violation of the Trading Provisions of Specimens of Endangered Wild Animal and Plant Species" was included only by the amendments of 10 October $2010^{18}$, it can be concluded that Latvia has fulfilled its obligation under CITES Article 8 Paragraph 1 "a" and has penalized offenders for violations of trade regulations worked into the convention by providing administrative liability.

The aforementioned amendments of the Criminal Law were based on the provision of Di-

\footnotetext{
${ }_{17}$ Trafficking procedure is clearly explained in the EU informative material. Skat.: http://ec.europa.eu/environment/cites/info_permits_en.htm (03.11.2018.)

${ }^{18}$ Grozījumi Krimināllikumā: Latvijas Republikas 2010. gada 21. oktobra likums. Latvijas Vēstnesis, 2010. 10. novembris, Nr. 178
} 
rective 2008/99/EC of the European Parliament and of The Council of 19 November 2008 on the protection of the environment through criminal law ${ }^{19}$, which provided penalizing criminal activity towards the environment.

That arises a rhetorical question, have regional obligations been more important to the Latvian legislator than the international? However, as it was previously explained, the protection of environment is a priority of the EU and the directive was adopted with the purpose of strengthening the general prevention and promote social disapproval of violations of legal acts in the field of environmental protection.

In the annotation ${ }^{20}$ of the amendments to the Criminal Law, the legislator has expressed, that prior to adding the new crime to the Criminal Law, it did not prescribe criminal liability for such actions. It is not clear though, why Section 190 "Smuggling" of the Criminal Law was not applicable, since the subject of the crime has always been explained as goods or other valuable properties, including all those movable items, for which there are no qualified constituent elements within the article or a special qualification in connection with movement of dangerous items.

\section{Preconditions of criminal liability}

Disposition of Section 115. ${ }^{1}$ of the Criminal Law expressis verbis includes three preconditions for criminal liability. Firstly, the object of a criminal offence or an actually existing material item, which is directly affected by a person, when committing a criminal offence. Secondly, the offence or a harmful and unlawful active (activity) or passive (failure to act) conduct. Thirdly, the harmful consequences or measurable public interests harm causedby unlawful behaviour.

A person's activity is criminal only in case if violations are detected regarding such specimens of wild fauna and flora, or their parts or products, which are recognized as endangered. In the particular case, by providing criminal liability, the legislator has decided to protect from harm the item of the criminal offence itself with the strongest protective means available to the state. Lacking an explanation of the item of the criminal offence in the Criminal Law and by systemically interpreting legal provisions, for a purposeful implementation of the Criminal Law, status of the movable specimen should be established in the special legislation acts of the sector, to be precise, in the CITES and the Basic Regulation. It must be noted that disposition of Section 115. ${ }^{1}$ of the Criminal Law is a blanket norm regarding the composition of the crime, for what reason the requirements for application of the criminal liability are to be found in the special laws and regulations of the sector. ${ }^{21}$ Criminal law is not an end in itself, but on the contrary it protects values recognized by the public and the procedures established in the laws and regulations of the sectors.

Under CITES a specimen is defined as any animal or plant, whether alive or dead, or any readily recognizable part or derivative thereof (Article 1 Section "b"). The Basic Regulation offers a clearly wider definition of a specimen - any animal or plant, whether alive or dead, any part or derivative thereof, as well as any other goods which are themselves or contain parts or derivatives of animals or plants of those species.

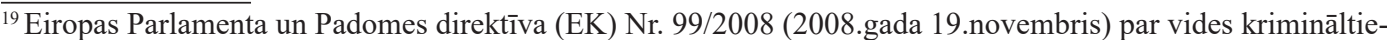
sisko aizsardzību. Eiropas Savienības Oficiālais Vēstnesis, L 328, 6.12.2008., 28.-37.lpp.

${ }^{20}$ 2010. gada 21. oktobra likumprojekta „Grozījumi Krimināllikumā” anotācija. Pieejama: http://titania.saeima. lv/LIVS/SaeimaLIVS.nsf/0/7318F47F694717E9C22576CB00505314?OpenDocument (02.03.2013.)

${ }^{21}$ Regarding blanket norms foreseeing criminal liability and interconnection of the legal acts of the sphere, see: Кузнецова Н.Ф. Проблемы квалификации преступлений: Лекции по спецкурсу «Основы квалификации преступлений». Науч. ред. и предисл. академика В.Н. Кудрявцева. Москва: Издательский Дом «Городец», 2007, c. 107. Accesible: http://www.ivurcol.net/el_resurs/4_kurs/problemy_kvalifikacii_prestupleniy.pdf (04.11.2018.)
} 
Assessing the biological status of the species and effect of the trade on its existence, the endangered species of the CITES are listed in three annexes:

Annex I includes species which are subject to extinction and which are affected by trade (or can be affected);

Annex II includes species, which are currently not subject to extinction, but which can become endangered, and other species, of which control is necessary, in order to effectively control the trade in the potentially endangered species (so called look-alike species);

Annex III includes species, which the member states have declared as objects of control in their jurisdiction and control of which requires international cooperation, which can be provided by the CITES.

Whereas the EU has classified the endangered species in four annexes (A, B, C, D), thus not only increasing the total number of the protected species, but also increasing the number of those species, which are declared to have the highest level of protection. ${ }^{22}$

In accordance with Article 2 Section "b" Subsection "ii" of the previously mentioned directive criminal liability is applicable for violations of trade procedures for species listed in Annex A and Annex B of the Basic Regulation. However, taking into account, that the object of criminal offence is not narrowed down in the disposition of Section $115 .^{1}$ of the Criminal Law, it can be concluded that criminal liability is prescribed for unlawful activities with any specimen included in the annexes of the Basic Regulation.It shall be noted that the member states of the EU have authority to establish stronger provisions that those, which are meant for achieving the purposes of directives, exactly how it is provided in Paragraph 12 of the preamble, for the purposes of utmost efficient penal protection of the environment.

It shall be indicated additionally, that in this occasion the case cannot be about activities with "specially protected species of animals and plants" on the contrary to what is mentioned in the commentary of the Criminal Law. ${ }^{23}$ Under Latvian legislative acts with thenotion "specially protected species of animals and plants" should be understood the species included in the list prescribed by the Cabinet of Ministers ${ }^{24}$. For their protection against illegal acquisition, keeping, destruction and damaging Section 115 of the Criminal Law is provided.

To ensure flexible implementation of the legal framework and to consider the vulnerability of the endangered specimens, criminal liability is provided for violations of any trade regulations if substantial harm has been caused, - international, regional or internal.

Even though trade is a notion, interpretation of which at first sight should not be a problem, still the definitions provided in the normative acts of the industry do not provide an unequivocal interpretation. Trade explained popularly is the action of buying, selling and changing of goods $^{25}$. Consequently trade is characterized by transition of goods from one person to other and material character of this activity. Under the Article 1 Section "c" of the CITES, trade means

\footnotetext{
${ }^{22}$ European Union. Wildlife Trade Regulations in the European Union. Luxembourg: Publications Office of the European Union, 2010, doi:10.2779/21758, page 11-12. Accesible: http://ec.europa.eu/environment/cites/pdf/ trade_regulations/short_ref_guide.pdf (03.11.2018.)

${ }^{23}$ Krimināllikuma komentāri. Otrā daḷa (IX-XVII nodaḷa). Krastiņš U., Liholaja V., Hamkova D. Rīga: Tiesu namu aǵentūra, 2016, 223. lpp.

${ }^{24}$ Noteikumi par īpaši aizsargājamo sugu un ierobežoti izmantojamo īpaši aizsargājamo sugu sarakstu: Ministru kabineta 2000. gada 14. novembra noteikumi Nr.396. Latvijas Vēstnesis, 2000. 17. novembris, Nr. 413/417

${ }^{25}$ In Latvian: Latviešu valodas interneta vārdnīca, šķirklis „tirdzniecība”. Accesible: http://tezaurs.lv/\#/sv/ tirdzniec\%C4\%ABba; 14.11.2018;

in English: Cambridge Dictionary, headword „trade”. Accesible: https://dictionary.cambridge.org/ $\mathrm{ru} / \% \mathrm{D} 1 \% 81 \% \mathrm{D} 0 \% \mathrm{BB} \% \mathrm{D} 0 \% \mathrm{BE} \% \mathrm{D} 0 \% \mathrm{~B} 2 \% \mathrm{D} 0 \% \mathrm{~B} 0 \% \mathrm{D} 1 \% 80 \% \mathrm{D} 1 \% 8 \mathrm{C} / \% \mathrm{D} 0 \% \mathrm{~B} 0 \% \mathrm{D} 0 \% \mathrm{BD} \% \mathrm{D} 0 \% \mathrm{~B} 3 \% \mathrm{D} 0$ \%BB $\%$ D0\%B8\%D0\%B9\%D1\%81\%D0\%BA\%D0\%B8\%D0\%B9/trade; 14.11.2018;

in Russian: Справочно-информационный портал „грамота.ру”, заглавное слово „торговля”. Accesible: http://gramota.ru/slovari/dic/?word=\%D1\%82\%D0\%BE\%D1\%80\%D0\%B3\%D0\%BE $\% \mathrm{D} 0 \% \mathrm{~B} 2 \% \mathrm{D} 0 \% \mathrm{~B}$ $\mathrm{B} \% \mathrm{D} 1 \% 8 \mathrm{~F} \&$ all $=x \& l o p=x \& b t s=x \& r o=x \& z a r=x \& a g=x \& a b=x \& \sin =x \& l v=x \& a z=x \& p=x ; 14.11 .2018$.
} 
import and introduction from the sea, export and re-export. In return Article 2 Section "u" of the BasicRegulation prescribes that trade shall mean the introduction into the Community, including introduction from the sea, and the export and re-export therefrom, as well as the use, movement and transfer of possession. Therefore, trade covers the process, in which the endangered specimen is being involved exposing to the risk of injury.

Considering the repressive nature of the criminal law, clarity and unequivocally of the Criminal Law is particularly crucial, however the scope of definition of trade provided in the Basic Regulation might seem too vague. Yet, by systemically interpreting the definition of trade provided in Section 115. ${ }^{1}$ of the Criminal Law and by observing the purposes of the regulations, in theory there is grounds for interpreting the definition of trade utmost broadly. Already now in theory of the criminal law there are separate examples, when the definitions used in the dispositions of the norms of the Criminal Law are interpreted over-stepping their traditional meaning. For example, acquisition means not only buying, leasing or changing, but also receiving as a gift and even keeping a finding or rather getting at one's disposal in any way. Whereasrealization includes not only those cases when for hand-over of goods an equivalent is received in return, but for gifting the goods, or rather hand-over to another person in any way. ${ }^{26}$

However, in order to promote reliability to the regulation, which is one of the preconditions for its observation, interpretation of legal norms should be balanced with comprehension of a reasonable individual. It must be noted that the possibilities embodied in the law can be fully utilized only if they reflect the requirements of the public and accordingly correspond to the judicial consciousness of the public. ${ }^{27}$

In the light of previously mentioned trade in context of the Criminal Law should be defined as a process or aggregate of activities, which includes taking the specimen out of its natural environment, displacement, subjecting the specimen to an unforeseen (uncharacteristic) risk and delivery to a new home. ${ }^{28}$

In this way, any deliberate participation in the illegal trade process is criminalized, because it is virtually impossible to severely divide the harmfulness of separate stages of the trade process. The commercial element and the transfer of title are not decisive, in particular given that trade in the most vulnerable specimens for direct commercialpurposes is prohibited. However, there are no grounds to believe that the endangered specimens are constantly on the market and, therefore, not every activity with the endangered specimens is considered a component of the trade. However widespread the interpretation of the notion of trade might be, it remains related to the transfer of the endangered specimen from one point to another.

To cover all possible cases of invasions of endangered specimens, considering that there is no principled significance regarding what activity exactly harms them, the Criminal Law should rather talk about unlawful circulation of the endangered specimens. Circulation or movement is a wider definition than trade, because it covers any unlawful activity with the endangered specimens. Until corresponding amendments are introduced criminal liability, for example, for

${ }^{26}$ See, f.e., commentary of professor Valentija Liholaja to the Section 233 of the Criminal Law regarding unauthorised acquisition and disposal of firearms, to the Section 248 regarding regarding unauthorised acquisition and disposal of powerfully acting substances (Krimināllikuma komentāri. Trešā daḷa (XVIII-XXV'1 nodaḷa). Krastiņš U., Liholaja V., Hamkova D. Rīga: Tiesu namu aǵentūra, 2016, 303., 305., 351.lpp.)

${ }^{27}$ Liholaja V. Tiesību normu efektivitātes jēedziens un kritēriji. Grām.: Vispārīgās tiesību teorijas un valststiesību atziņas. Rīga: Latvijas Universitāte, 1997, 94.-96.lpp.

${ }^{28}$ About the harmful effect of illegal wildlife transportation see: Wyatt T. Wildlife Trafficking. A Deconstruction of the Crime, the Victims and the Offenders. London: Palgrave Macmillan, 2013, p. 67.-70. 
a lawfully moved endangered specimen deliberate unlawful or unacceptable use should be provided in a different section of the Criminal Law.

Based on the above, it is cleared that criminal liability is currently foreseen for any violation of the trade regulations, if it causes substantial harm, that is, both for smuggling and other breaches of trade regulations.

Smuggling means the introduction of the specimens into the territory of the state or exporting out of it, by misleading the customs authorities as to the identity, number or the fact of the movement itself. Smuggling manifests itself when the responsible person avoids customs control and moves the endangered specimens without declaring them or declaring them improperly. ${ }^{29}$

Other violations are related to non-compliance with the specific protection requirements of the endangered specimens. In the process of trade of the endangered specimens, their health or life can be endangered in several ways.

For example, improper preparation of the endangered specimen for transportation and unsafe transportation, where the risk of causing damage is not decreased to the minimum (Paragraph 11 of the preamble of the Basic Regulation provides interpretation of its provisions in a way to minimize the adverse effects on live specimens), inadequate care during transportation of the endangered specimens (Basic Regulation provides issuing the permits for import only if the place of destination provides housing for a living specimen that will be adequately equipped for preservation and care (Article 4 Part 1 Section "c", Article 2 Section "b" of the Basic Regulation)). Also where, in the marking of live animals requires to be undertaken with due regard to humane care, well-being and natural behaviour of the specimen concerned, as it is prescribed by Article 67 of the Implementation Regulation.

Violation of regulations in trade of endangered animals and plants is penalized considering the popularly used threshold of criminal liability under the Criminal Law - causing substantial harm as a result of criminal offence. This valuation definition is comfortable for legislator, because in theory it provides a possibility the significance of each separate occasion, however often enough in practice it is problematic to fill it with content, when separate applications of the norm are in different views regarding reaching the necessary level of significance of harm for provision of criminal liability.

Substantial harm as characterization of harmful consequences directly testifies that as a result of criminal offence, negative changes to the surrounding environment are made, which are subject to assessment. Section 23 of the Law On the Procedures for the Coming into Force and Application of The Criminal $\mathrm{Law}^{30}$ provides that causing substantial harm shall apply if due to the criminal offence any of the following consequences have set in:

1) property loss has been suffered which has been not less than the total of five minimum monthly wages ${ }^{31}$, and also other interests protected by law have been threatened;

2) property loss has been suffered which has been not less than the total of ten minimum monthly wages;

3) other interests protected by law have been significantly threatened.

${ }^{29}$ Čevers T. Kontrabandas krimināltiesiskie aspekti. Rīga: SIA „Pārdaugavas juridiskais birojs”, 2015, 4., 89.-91. lpp.

${ }^{30}$ Par Krimināllikuma spēkā stāšanās un piemērošanas kārtību: Latvijas Republikas 1998. gada 15. oktobra likums. Latvijas Vēstnesis, 1998. 4.novembris, Nr.331/332

${ }^{31}$ Minimum wage in 2018 Latvia is established in amount of EUR 430 (Noteikumi par minimālās mēneša darba algas apmēru normālā darba laika ietvaros un minimālās stundas tarifa likmes aprēkināšanu: Latvijas Republikas Ministru kabineta 2015.gada 24.novembra noteikumi Nr. 656. Latvijas Vēstnesis, 2015. 26.11, Nr. 232) 
Before application of the aforementioned criteria, their application problems can already be suspected. Firstly, as a surprise the legislator has not restricted the interests in the Section 115. ${ }^{1}$ of the Criminal Law, to which as a result of a criminal offence a substantial harm could be caused. Perhaps, in this way in order to maximize the protection of the subject of a criminal offence, it is intended to guarantee the broadest possible application of the section. Theoretically substantial harm could be caused, for example, to the economy or public health, as a result of trade in the endangered specimens, if together with the specimens some causative agents or pests are moved. Secondly, taking into account, that trade in the most vulnerable endangered specimens for commercial purposes is prohibited, it is not clear, how to assess the amount of the caused harm in money. Thirdly, the substantial harm must be caused in coherence with the criminal offence, namely, it must be caused directly by the illegal trade.

Therefore, the question remains, what will testify substantial harm to the interests of protection of environment and particularly in the case, when illegal trade has happened only with dead specimens or their products. In this way a certain doubt exists regarding whether foreseeing criminal liability can be effective enough, which contravenes the purpose of the aforementioned action plan to more effectively fight the illegal trade in endangered specimens. It must be remembered, that by adding the substantial harm element to the disposition, strict separation of administrative violations and criminal offenses is achieved. Any violations of the regulations always cause at least a hypothetical harm. However, in order to establish the basis of criminal liability, not only must the harm be caused, but the harm caused by this offence must be significant - substantial.

Part three of Section 23 of the aforementioned law declares that the criteria for endangering of the interests protected by law resulting from criminal offences may be specified in annexes to this law. Unfortunately, an annex, which includes criteria for establishing threat to the environment in the aspect under consideration, has not been developed so far. The directive according to which the Criminal Law was supplemented with the new criminal offense, does not significantly ease the interpretation of this assessment, but at least contains a reference to the evaluation of the quantitative and qualitative criteria. Section "g" Article 3 of the Directive provides that trading in specimens of protected wild fauna and flora is not considered criminal in cases where the conduct concerns a negligible quantity of such specimens and has negligible impact on the conservation status of the species. By modelling potential substantial harm variants, it is believed that the most realistic cases of substantial harm are likely to be serious injuries or deaths of the endangered specimens due to breaches of trade regulations. Namely, for establishing a caused substantial harm it would be enough with deaths of several less protected endangered specimens or at least one serious injury of a specially protected specimen.

It should be taken into account, that detecting substantial harm reflects the impact of the violation on the survival possibilities of the specific species in the wild. Such approach would also correspond with implementing justice in the fundamental individualization of guilt and punishment.

\section{Conclusions}

Criminal liability pursuant to Section $115 .^{1}$ of the Criminal law is foreseen for deliberate participation in trade of the specimens included in the annexes A, B, C and D of the Basic Regulation thus violating the requirements of the sectoral regulatory enactments, if in this way substantial harm to any interests protected under law is caused. 
In order to fulfil the demand of the international public for the effective fight against the environmental crime, it is necessary to not only strengthen the understanding of the preconditions to protection of the endangered species under criminal law, but also the states must follow a more unified approach in establishment of the preconditions of criminal liability.

In order to ensure the judges are timely ready for dealing with cases of illicit movement of endangered wild animals and plants, the cooperation between industry specialists and criminal law researchers, by analysing and clarifying the preconditions for criminal liability and by establishing substantial harm criteria, should be promoted with the purpose of making application of Section 115. ${ }^{1}$ of the Criminal Law more effective.

Complicated, contradictory and unclear legal framework is hardly applicable. Not only does it prevent dishonest people from circumventing it, but it also hinders consumer caution, when they unknowingly become the supporters of criminal networks.

\section{References:}

1. 2010. gada 21. oktobra likumprojekta „Grozījumi Krimināllikumā” anotācija. Pieejama: http:/titania.saeima.lv/LIVS/SaeimaLIVS.nsf/0/7318F47F694717E9C22576CB00505314?OpenDocument (02.03.2013.)

2. About the harmful effect of illegal wildlife transportation see: Wyatt T. Wildlife Trafficking. A Deconstruction of the Crime, the Victims and the Offenders. London: Palgrave Macmillan, 2013, p. 67.-70.

3. Accesible: http://www.wcoomd.org/en/topics/enforcement-and-compliance/resources/publications.aspx(03.11.2018.)

4. Action Plan against Wildlife Trafficking, European Commision. Brussels, COM/2016/087 final. Accesible: https://eur-lex.europa.eu/legal-content/EN/TXT/PDF/?uri=CELEX:52016DC0087\&from=EN (03.11.2018.)); Action Plan is demonstratively explained in the publication: European Union. EU Action Plan against Wildlife Trafficking, European Commision (COM (2016) 87 final). Luxembourg: Publications Office of the European Union, 2016. doi:10.2779/016138. Accesible: http://ec.europa.eu/environment/cites/pdf/WAP_EN_WEB.PDF (03.11.2018.)

5. Commission Staff Working Document on the EU Action Plan against Wildlife Trafficking. European Commision. Brussels, SWD/2016/038 final, page 27. Accesible: https://eur-lex.europa. eu/legal-content/EN/TXT/?uri=SWD:2016:38:FIN (03.11.2018.); Emphasizing directly the loss of habitats as the main reason for extinction of the endangered species, critical remarks regarding significance of CITES in preserving the biological diversity have been made (A du Plessis Morne. CITES and the Causes of Extinction. Book: Endangered Species, Threatened Convention: The Past, Present and Future of CITES. Edited by Jon Hutton and Barnabus Dickson. London: Earthscan Publications Ltd, 2000, p. 22-23)

6. Commission Staff Working Document on the EU Action Plan against Wildlife Trafficking. European Commision. Brussels, SWD/2016/038 final, page 7, 8, 10. Accesible: https://eur-lex.europa.eu/legal-content/EN/TXT/?uri=SWD:2016:38:FIN (03.11.2018.)

7. Čevers T. Kontrabandas krimināltiesiskie aspekti. Rīga: SIA „Pārdaugavas juridiskais birojs”, 2015, 4., 89.-91.lpp.

8. Eiropas Parlamenta un Padomes direktivva (EK) Nr. 99/2008 (2008.gada 19.novembris) par vides krimināltiesisko aizsardzību. Eiropas Savienības Oficiālais Vēstnesis, L 328, 6.12.2008., 28.37.lpp.

9. European Union. Wildlife Trade Regulations in the European Union. Luxembourg: Publications Office of the European Union, 2010, doi:10.2779/21758, page 8. Accesible: http://ec.europa. eu/environment/cites/pdf/trade_regulations/short_ref_guide.pdf (03.11.2018.); Wijnstekers W. The Evolution of CITES - 9th Edition. International Council for Game and Wildlife Conservation, 2011, page 32. Accesible: https://cites.org/sites/default/files/common/resources/Evolution_of_CITES_9. pdf (03.11.2018.) 
10. European Union. Wildlife Trade Regulations in the European Union. Luxembourg: Publications Office of the European Union, 2010, doi:10.2779/21758, page 11-12. Accesible: http://ec.europa.eu/environment/cites/pdf/trade_regulations/short_ref_guide.pdf (03.11.2018.)

11. Grozījumi Krimināllikumā: Latvijas Republikas 2010. gada 21. oktobra likums. Latvijas Vēstnesis, 2010. 10. novembris, Nr. 178

12. Gulbis A., Čevers A. Muitas darbības pamati. Papildināts un pārstrādāts izdevums. Rīga: RTU Izdevniecība, 2010, 27., 28.1pp.

13. Ignats M., Gulbis A. 1973. gada Vašingtonas konvencijas par starptautisko tirdzniecību ar apdraudētajām dzīvnieku un augu sugām (CITES) noteikumi un to piemērošana. Rīga: RTU Muitas konsultatīvais centrs, 2003, 3.lpp.

14. in English: Cambridge Dictionary, headword „trade”. Accesible: https://dictionary.cambridge.org/ru/\%D1\%81\%D0\%BB\%D0\%BE\%D0\%B2\%D0\%B0\%D $\% \% 80 \% \mathrm{D} 1 \% 8 \mathrm{C} / \% \mathrm{D} 0 \% \mathrm{~B} 0$ $\% \mathrm{D} 0 \% \mathrm{BD} \% \mathrm{D} 0 \% \mathrm{~B} 3 \% \mathrm{D} 0 \% \mathrm{BB} \% \mathrm{D} 0 \% \mathrm{~B} 8 \% \mathrm{D} 0 \% \mathrm{~B} 9 \% \mathrm{D} 1 \% 81 \% \mathrm{D} 0 \% \mathrm{BA} \% \mathrm{D} 0 \% \mathrm{~B} 8 \% \mathrm{D} 0 \% \mathrm{~B} 9 /$ trade; 14.11.2018;

15. In Latvian: Latviešu valodas interneta vārdnīca, šķirklis „tirdzniecība”. Accesible: http:// tezaurs.lv/\#/sv/tirdzniec\%C4\%ABba; 14.11.2018;

16. in Russian: Справочно-информационный портал „грамота.ру”, заглавное слово „торговля”. Accesible: http://gramota.ru/slovari/dic/?word=\%D1\%82\%D0\%BE\%D1\%80\%D0\% B3\%D0\%BE $\%$ D0\%B2\%D0\%BB $\%$ D $1 \% 8$ F \&all=x\&lop=x\&bts=x\&ro=x\&zar=x\&ag=x\&ab=x$\& \sin =x \& l v=x \& a z=x \& p e=x ; 14.11 .2018$.

17. Komisijas Regula (EK) Nr. 865/2006 (2006. gada 4. maijs), ar ko paredz sīki izstrādātus noteikumus attiecībā uz Padomes Regulas Nr. 338/97 par savvaḷas dz̄ivnieku un augu sugu aizsardzību, reglamentējot to tirdzniecību, ieviešanu. Eiropas Savienības Oficiālais Vēstnesis, L 166, 19.6.2006., 1.-69.lpp.

18. Krimināllikuma komentāri. Otrā daḷa (IX-XVII nodaḷa). Krastiņš U., Liholaja V., Hamkova D.. Rīga: Tiesu namu ağentūra, 2016, 223. lpp.

19. Liholaja V. Tiesību normu efektivitātes jēdziens un kritēriji. Grām.: Vispārīgās tiesību teorijas un valststiesību atziñas. Rīga: Latvijas Universitāte, 1997, 94.-96.lpp.

20. Martin R.B. When CITES Works and when it Does Not. Book: Endangered Species, Threatened Convention: The Past, Present and Future of CITES. Edited by Jon Hutton and Barnabus Dickson. London: Earthscan Publications Ltd, 2000, p. 32

21. Minimum wage in 2018 Latvia is established in amount of EUR 430 (Noteikumi par minimālās mēneša darba algas apmēru normālā darba laika ietvaros un minimālās stundas tarifa likmes aprēkināšanu: Latvijas Republikas Ministru kabineta 2015.gada 24.novembra noteikumi Nr. 656. Latvijas Vēstnesis, 2015. 26.11, Nr. 232)

22. Noteikumi par īpaši aizsargājamo sugu un ierobežoti izmantojamo īpaši aizsargājamo sugu sarakstu: Ministru kabineta 2000. gada 14. novembra noteikumi Nr.396. Latvijas Vēstnesis, 2000. 17. novembris, Nr. $413 / 417$

23. Padomes Regula (EK) Nr. 338/97 (1996. gada 9. decembris) par savval̦as dzīvnieku un augu sugu aizsardzību, reglamentējot to tirdzniecību. Eiropas Savienības Oficiālais Vēstnesis, L 61, 3.3.1997., 1.-69.lpp.

24. Par Krimināllikuma spēkā stāšanās un piemērošanas kārtību: Latvijas Republikas 1998. gada 15. oktobra likums. Latvijas Vēstnesis, 1998. 4.novembris, Nr.331/332

25. Par starptautisko tirdzniecību ar apdraudētajām savvaḷas dzīvnieku un augu sugām: 1973. gada 3.marta starptautisks līgums. Latvijas Vēstnesis, 1997. 7.janvāris, Nr. 3/4

26. Regarding blanket norms foreseeing criminal liability and interconnection of the legal acts of the sphere, see: Кузнецова Н.Ф. Проблемы квалификации преступлений: Лекции по спецкурсу «Основы квалификации преступлений». Науч. ред. и предисл. академика В.Н. Кудрявцева. Москва: Издательский Дом «Городец», 2007, с. 107. Accesible: http://www.ivurcol.net/el_ resurs/4_kurs/problemy_kvalifikacii_prestupleniy.pdf (04.11.2018.)

27. See, f.e., commentary of professor Valentija Liholaja to the Section 233 of the Criminal Law regarding unauthorised acquisition and disposal of firearms, to the Section 248 regarding regarding unauthorised acquisition and disposal of powerfully acting substances (Krimināllikuma komentāri. 
Trešā daḷa (XVIII-XXV¹ nodaḷa). Krastiņš U., Liholaja V., Hamkova D. Rīga: Tiesu namu aǵentūra, 2016, 303., 305., 351.lpp.)

28. Specimens of endangered species in Latvia are affected the least by international trade, because conservation of species is mainly affected by the decrease of quality and space of the habitats (1973.gada Vašingtonas konvencijas par tirdzniecību ar apdraudētajām savvaḷas dzīvnieku un augu sugām (CITES) ieviešana Eiropas Savienībā un Latvijā. Autoru kolektīvs. [B.v.]: Dabas aizsardzības pārvalde, [b.g.], 50.lpp. Accesible: https://www.daba.gov.lv/upload/File/Publikacijas/ROKASGR CITES 2008.pdf (03.11.2018.))

29. Sugu un biotopu aizsardzības likums: Latvijas Republikas 2000. gada 16. marta likums. Latvijas Vēstnesis, 2000. 5. aprīlis, Nr. 121/122

30. The EU is not only one of the transit regions of endangered species of wild fauna and flora, but also the biggest destination of the illegal import. (Commission Staff Working Document on the EU Action Plan against Wildlife Trafficking. European Commision. Brussels, SWD/2016/038 final, page 4, 15, 16. Accesible: https://eur-lex.europa.eu/legal-content/EN/TXT/?uri=SWD:2016:38:FIN (03.11.2018.)

31. Trafficking procedure is clearly explained in the EU informative material. Skat.: http://ec.europa.eu/environment/cites/info_permits en.htm (03.11.2018.)

32. Wijnstekers W. The Evolution of CITES - 9th Edition. International Council for Game and Wildlife Conservation, 2011, page 25. Accesible: https://cites.org/sites/default/files/common/resources/Evolution of CITES 9.pdf (03.11.2018.); Daan P. van Uhm. The Illegal Wildlife Trade: Inside theWorld of Poachers, Smugglers and Traders. Springer International Publishing Switzwerland, 2016, p. 36, 41

33. World Customs organization. Illicit Trade Report 2016, page 106. Accesible: http://www. wcoomd.org/-/media/wco/public/global/pdf/topics/enforcement-and-compliance/activities-and-programmes/illicit-trade-report/itr-2016-en.pdf?db=web (03.11.2018.)

\title{
ПЕРЕДУМОВИ КРИМІНАЛЬНО-ПРАВОВОЇ ОХОРОНИ МІЖНАРОДНОГО ОБГГУ ВИДІВ ФАУНИ ТА ФЛОРИ, ЩО ЗНАХОДЯТЬСЯ ПІД ЗАГРОЗОЮ ЗНИКНЕННЯ ЗГЦДНО КРИМІНАЛЬНОГО КОДЕКСУ ЛАТВІЇ
}

\author{
Том ШЕВЕРС, \\ Латвійський університет, Рига, Латвія \\ toms.cevers@gmail.com
}

У статті висвітлено необхідність охорони юридично обтрунтованого міжнародного обігу зникаючих видів дикої фауни та флори та з'ясовано митну роль у забезпеченні їх юридично обтрунтованого міжнародного обігу. Аналізуючи міжнародне, регіональне (Европейський Союз) та місиеве (Кримінальний кодекс та Кодекс Латвії про адміністративні правопорушення) законодавство, визначаються передумови кримінальної відповідальності за порушення положень щздо торгівлі зникаючими видами дикої фауни та флори: (1) визначено об'єкт кримінального правопорушення, (2) визначено термін «торговельні положення», (3) охарактеризовано істотну шкоду як негативний наслідок, спричинений кримінальним правопорушенням. Зроблено висновок, щчо розділ $115^{1}$ «Порушення правил торгівлі видами диких тварин та рослин, щчо знаходяться під загрозою виникнення» Кримінального кодексу потребує доктринальних пояснень для підвищення ефективності забезпечення верховенства права. Проаналізовано складові елементи кримінального правопорушення, описані у розділі $115^{1}$ Кримінального кодексу, для забезпечення його законності відповідно до сенсу та мети з урахуванням міжнародних зобов'язань з метою підвищення рівня захисту зникаючих видів фауни та флори, пов'язаних з міжнародною торгівлею.

Для того, щоб задовольнити міжнародну спільноту стосовно ефективної боротьби з екологічною злочинністю, необхідно не лише посилити розуміння передумов захисту зникаючих видів, передбачених кримінальним законодавством, але $i$ дотримуватися єдиного підходу до встановлення передумов кримінальної відповідальності.

Ключові слова: вимираючі види фауни та флори, Конвенція про міжнародну торгівлю видами дикої фауни та флори (CITES), кримінальна відповідальність, митниця, незаконна торгівля, міжнародний обіг товарів, міжнародна торгівля. 